\title{
Emerging Model of Questioning through the Process of Teaching and Learning Electrochemistry
}

\author{
Zanaton Haji Iksan ${ }^{1} \&$ Esther Daniel ${ }^{2}$ \\ ${ }^{1}$ Faculty of Education, Universiti Kebangsaan Malaysia, Malaysia \\ ${ }^{2}$ Faculty of Education, University of Malaya, Malaysia \\ Correspondence: Zanaton Haji Iksan, Faculty of Education. Universiti Kebangsaan Malaysia, 43600 Bangi \\ Selangor Darul Ehsan, Malaysia. Tel: 19-600-4627. E-mail: zanatonmdnoor@yahoo.com
}

Received: April 4, 2014 Accepted: May 4, 2015 Online Published: September 28, 2015

doi:10.5539/ies.v8n10p137 URL: http://dx.doi.org/10.5539/ies.v8n10p137

\begin{abstract}
Verbal questioning is a technique used by teachers in the teaching and learning process. Research in Malaysia related to teachers' questioning in the chemistry teaching and learning process is more focused on the level of the questions asked rather than the content to ensure that students understand. Thus, the research discussed in this paper is intended to explore in-depth the types of questions posed by teachers when teaching electrochemistry. This topic was chosen as it is categorized as a difficult topic by both students and teachers. This research employed qualitative techniques in exploring teachers' verbal questioning during the teaching process. Participants included five teachers teaching Chemistry Form 4 (Grade 10). The data were collected through non-participant observations and verbatim recordings during the teaching and learning process. The findings indicate that the types of teachers' verbal questions when teaching electrochemistry can be categorized in two main areas: content and management questions. Content questions could be sub-divided into five sub-categories: linking questions, questions based on process, comparison questions, questions based on students' observations, and questions based on terminology. As for the management questions, they consisted of four sub-categories: questions for probing, monitoring, and motivation as well as bilingual questions. The data analysis also showed that the content and management questions are complementary as both types are needed in the verbal questioning process during the teaching and learning of electrochemistry.
\end{abstract}

Keywords: questioning, type of question, model, electrochemistry

\section{Introduction}

Verbal questioning has been identified as one of the important strategies in the teaching and learning process (Chiappetta \& Koballa, 2006) and is reliable for effective teaching and learning (Cimer, 2007). Verbal questioning can also be a measurement of successful teaching (Sahin, 2007). Thus, besides content, teachers must also have effective teaching strategies (Parkway \& Hardcastle, 1990). Some of the reasons for using verbal questions in the teaching and learning process is to give students opportunities to use their thinking skills, increase curiosity, motivate personal learning, increase interest, and be actively involved in the learning process. For the teacher, verbal questioning helps assess students' understanding (Fries-Gaither, 2008).

In the context of the actual classroom, teachers' questions are more dominant compared to students' questions. Indirectly, questioning in the class refers to teachers' questioning (Dillon, 1990). Research demonstrated that teachers' questioning in the class depended on their knowledge and activities (Carlsen, 1991). The questions posed by the teachers in the class could increase the understanding as well as identify students' misconceptions (Chin \& Kayalvizhi, 2002; Teixeira-Dias et al., 2005).

Thus, teachers' verbal questioning can be used as an evaluation process throughout the teaching period in order to determine students' understanding of the concepts, monitor the teaching process as well as motivate students' participation in the teaching process (Noraini \& Osman, 2009). Hence, teachers play a major role in developing students' minds through verbal questions (Skamp, 2004). In addition, teachers must empower the teaching content and draw connections for ensuring students' understanding of the topic learned. In science teaching, teachers' questions are an important element for identifying the process of how students understand the concept by motivating the students to explain, clarify, and develop ideas based on the answers given, thereby rooting out 
the hidden ideas in students' minds that oppose the learned concept. This method promotes student-centered approaches, where the students are actively involved in the science learning and teaching process. Teachers who rely heavily on this method ensure that students will not only get the knowledge, but also develop other skills.

Indeed, most questions in the class begin from the teachers, and teachers can ask up to 80 questions in a one-hour teaching session. However, research findings in Malaysia showed that the questions posed by teachers are less challenging and at a lower level (Arfah, 1981; Jamil, 1993; Bachik, 1999; Lim \& Mahamod, 2007; Othman, 2007). Related to the concept of empowerment, Daniel (1999) found that only one third of understanding takes place in students' mind while two thirds is lost information and cannot be learned, understood, or accurately conceived. This phenomenon can probably be overcome if teachers can assess students' knowledge and draw connections to the learned concept while posing questions during teaching, especially for complex concepts. Good verbal questions during teaching can increase the basic understanding of certain concepts to overcome misconceptions (Tamby, 1999).

As discussed, teachers' questions in the classroom are more dominant than students' questions. However, what types of questions do teachers use in the teaching and learning process to understand certain concepts? The teacher should have a clear picture about the subject content so that the questions asked will develop students' understanding. Moreover, teachers' types of questions cover not only the teaching content, but also other questions used to ensure the overall understanding about a particular topic. Thus, this paper intends to explore the types of questions posed by teachers during the teaching and learning process in electrochemistry. Electrochemistry is considered a difficult topic among students (Chan, 1990; Masrukin, 2004). It involves a lot of basic concepts derived from previous topics. Therefore, a solid understanding of the basic concepts is essential to facilitate a greater understanding of the concepts in electrochemistry.

\subsection{Types of Questions}

In the process of teaching and learning, oral questions are dominated by teachers since they are the ones responsible in ensuring that learning takes place (Smith \& Barrow, 1996). Oral questions during the teaching process act as tools to achieve educational goals, which are to stimulate students' thinking, enhance their communication skills, improve their cognitive development, and to assess the effectiveness of teaching. Therefore, teachers use a variety of questions in order to achieve that goal.

Generally, oral questions are categorized into two types of questions that contradict; closed-opened, convergent-divergent and easy-hard oral questions. Closed oral questions frequently used when teachers require students to provide certain information or facts, especially in early instruction. These questions involve short answers, factual and require one or two words. Teachers also expect specific answers to be accepted as correct. This question is also categorized as a simple question because it requires a simple answer.

On the other hand, opened oral questions are oral questions that involve answers that are long, varied and require clarification or explanation based on what is in their minds. Opened oral questions give way to more advanced thinking through dialogue between teachers and students on an ongoing basis (Vella, 2008). Therefore, opened question is also categorized as divergent questions, which have several possible responses, and requires students to develop and organize ideas before responding.

Both types of oral questions has its own role in the teaching process, in which closed oral questions are more likely to be used for accompanying opened oral questions raised in the early stages and aims to focus on the thoughts of students on the concepts discussed. The uses of both types of oral questions are important and complementary in the process of teaching and learning to ensure the development of students' understanding. Smith and Barrow (1996) have involved these two types of questions into the Question Category System for Science (QCSS). Question Category System for Science has been developed and categorized into four types of questions, which are opened oral questions (open-ended), closed oral question (closed-ended), oral questions related to class management (managerial) and rhetorical questions.

Teachers' oral questions are also categorized based on the cognitive development referring to Bloom's Taxonomy of cognitive levels (Chiappetta \& Koballa 2006). He classified the type of oral questions by linking oral questions that use 4W (What, Why, Who, Where) and H (How). In this case, Vella (2008) stated that an opened oral question often starts with 'how', as it involves processes. Therefore, there is a relationship between the opened oral question "how" with students' metacognitive awareness (Koufetta-Menicou \& Scaife, 2000).

In addition, the classification of oral questions is not only in terms of cognitive, but also take into account the overall goal of education, by including the concept of values in teaching. Therefore, Wragg and Brown (2001) categorized the types of oral questions into several contexts, which are conceptual, empirical and value. He 
classified the type of oral questions into three categories, which were oral questions that are used for conceptual understanding (conceptual question), empirical oral questions which are questions that are used to obtain information (information/data) during the course of experimenting with the students, and oral questions that link values with the knowledge learned.

All kinds of questions discussed have certain foundation depending on how the teacher wants to achieve the learning goals during the process of teaching and learning. The use of oral questions should be diversified so that the learning environments in the classroom become attractive and acceptable to all students because each individual has different trait, attitude and tendencies.

\section{Method}

In exploring the type of verbal questions posed by chemistry teachers during the teaching and learning process, qualitative data was collected. The qualitative method is suitable for in-depth research in any phenomenon, activity, and process (Creswell, 2003). The qualitative approach was chosen to observe the process of verbal questioning in the natural classroom (Merriam, 2009).

\subsection{Participants}

The participants consisted of five teachers who teach chemistry subject. A total of five participants were chosen through purposive sampling. They were selected based on specific criteria to ensure that those selected have rich information regarding the issues (Merriam, 2009). These criteria are as follows: the teacher must have majored in chemistry, be teaching electrochemistry in form four, have attended science orientation course, and be willing to participate in this study. The science orientation course is important because this course discusses the inquiry concept, including oral questioning. Detailed information about the selected participants is shown in Table 1. The length of teaching experiences ranged from 5 to 24 years and experience teaching chemistry ranged from 2 to 22 years. All teachers were qualified in their subject matters and also had educational qualifications.

Table 1. Participants' backgrounds

\begin{tabular}{lcccl}
\hline \multirow{2}{*}{ Name } & Old & \multicolumn{2}{c}{ Teaching experiences } & \\
\cline { 3 - 4 } & & $\begin{array}{c}\text { All } \\
\text { (Year) }\end{array}$ & $\begin{array}{c}\text { Chemistry } \\
\text { (Year) }\end{array}$ & \\
\hline Nora & 43 & 17 & 10 & Bachelor of Science, Master of Education, Diploma of Education \\
Roha & 40 & 13 & 12 & Bachelor in Chemical Engineering, Diploma of Education \\
Rosni & 42 & 11 & 11 & Bachelor in Biotechnology, Diploma of Education \\
Salina & 30 & 5 & 2 & Bachelor of Science (Chemistry), Diploma of Education \\
Zai & 51 & 24 & 22 & Bachelor in Science Education \\
\hline
\end{tabular}

Note. The names listed are nicknames.

\subsection{Data Collection}

To gather data in the form of questions posed by teachers during teaching, the researcher asked for permission to record lessons using an MP3 player hung around participants' necks. Participants were asked to use audio recording devices; all agreed. Five teaching sessions were recorded. The researcher did not participate in the class, but rather sat at the back of the room during the lessons. Based on the observations and recordings, the researcher prepared a transcription to reproduce teachers' teaching verbatim. Teachers' teaching transcription included the dialogue between teachers and students plus the researcher's observations. The researcher then conducted interviews to explore the intention of using certain questions more deeply.

The teaching observation about electrochemistry carried out in three to four sessions. Chemistry was taught in two lessons a week, and each lesson involves two 35- to 40-minute sessions for 70 to 80 minutes per lesson. Typically, electrochemistry is taught in eight sessions during four weeks. However, in this study not all teaching sessions were observed for each teacher. These constraints caused part of the learning to take place at roughly the same time for the five teachers. Overall, four observations were recorded for each participant.

\subsection{Analyzing}

All teachers' teaching verbatims were analyzed to decide the theme according to the types of questions identified 
and the intention of the verbal questions. In the process of analysis, thematic analysis was carried out where the formation of themes developed continuously through constant comparative analysis techniques. Four steps were done in this process; First, reading the verbatim data to identify excerpts that can depict a theme; Second, the reading is continued to identify other excerpt, if there is an excerpt that has the same depiction with the theme that has been formed, then this paragraph is included in the same theme; Third, if the identified sentence is not suitable to be included in the same theme, a new theme is formed; Fourth, the process of forming themes continues until the data analysis is completed. This process is repeated continuously for different data.

\section{Results and Discussion}

Based on the analysis of each question posed by the teachers during the teaching sessions, the questions were divided into two main categories: content questions and management questions. Table 2 shows the number and percentage of questions in each category. Content questions are those questions related to the electrochemistry content whereas management questions are those that are needed for and that complement the oral questioning process, which involves the management of comprehensive teaching and learning in the classroom. These kinds of verbal questions ensure that lessons run smoothly and continuously.

The findings show that the number of questions posed by the teachers varies; Nora posed 80-109, Roha 162-224, Rosni 214-317, Salina 129-213, and Zai 145-162. In general, the percentage of questions related to content is higher than the percentage of questions related to management during the teaching session. However, some sessions had more management questions than content questions, especially during experiment sessions in the science laboratory.

Table 2. Number of verbal questions posed in four teaching sessions

\begin{tabular}{|c|c|c|c|c|c|c|c|c|}
\hline \multirow[b]{3}{*}{ Name } & \multicolumn{2}{|c|}{1} & \multicolumn{2}{|c|}{2} & \multicolumn{2}{|c|}{3} & \multicolumn{2}{|c|}{4} \\
\hline & CQ & MQ & CQ & MQ & CQ & MQ & CQ & MQ \\
\hline & $F(\%)$ & $F(\%)$ & $F(\%)$ & $F(\%)$ & $F(\%)$ & $F(\%)$ & $F(\%)$ & $F(\%)$ \\
\hline Nora & $62(73.8)$ & $22(26.2)$ & 54(65.8) & $28(34.1)$ & $57(71.2)$ & $23(28.8)$ & $71(65.1)$ & $38(34.9)$ \\
\hline Total & \multicolumn{2}{|c|}{84} & \multicolumn{2}{|c|}{82} & \multicolumn{2}{|c|}{80} & \multicolumn{2}{|c|}{109} \\
\hline Roha & $92(55.4)$ & $74(44.6)$ & $112(50.0)$ & $112(50.0)$ & $122(75.3)$ & $40(24.7)$ & $74(45.1)$ & $90(54.9)$ \\
\hline Total & \multicolumn{2}{|c|}{166} & \multicolumn{2}{|c|}{224} & \multicolumn{2}{|c|}{162} & \multicolumn{2}{|c|}{164} \\
\hline Rosni & $185(58.4)$ & $132(41.6)$ & & & $109(48.2)$ & $117(51.8)$ & $135(63.1)$ & $79(36.9)$ \\
\hline Total & \multicolumn{2}{|c|}{317} & & & \multicolumn{2}{|c|}{226} & \multicolumn{2}{|c|}{214} \\
\hline Salina & $138(76.7)$ & $42(23.3)$ & $100(83.3)$ & $20(16.7)$ & $94(78.3)$ & $26(21.7)$ & $182(85.4)$ & $31(14.5)$ \\
\hline Total & \multicolumn{2}{|c|}{180} & \multicolumn{2}{|c|}{120} & \multicolumn{2}{|c|}{120} & \multicolumn{2}{|c|}{213} \\
\hline Zai & $85(58.6)$ & $60(41.4)$ & $85(58.6)$ & $60(41.4)$ & & & $50(30.3)$ & $115(69.7)$ \\
\hline Total & \multicolumn{2}{|c|}{145} & \multicolumn{2}{|c|}{145} & & & \multicolumn{2}{|c|}{162} \\
\hline
\end{tabular}

Note. 1, 2, 3, 4-teaching session;

CQ: Content Question;

MQ: Management Question;

F: Frequency (Number of verbal questions).

Further analysis revealed that questions related to content consists of five sub-categories: recall questions, questions based on process, comparison questions, questions based on observation, and questions based on terminology. Meanwhile, management questions consist of four sub-categories: monitoring questions, motivating questions, bilingual questions, and prompting questions. Table 3 provides an example of questions posed by the 
teachers related to their type of question.

Table 3. Sample questions for each category and types of sub-categories

\begin{tabular}{|c|c|c|c|}
\hline Category & $\begin{array}{l}\text { Sub-category } \\
\text { question }\end{array}$ & Question example & Remarks \\
\hline \multirow[t]{9}{*}{$\begin{array}{l}\text { Content } \\
\text { question }\end{array}$} & Recall question & $\begin{array}{l}\text { - Can you remember the properties } \\
\text { of the ionic compound? }\end{array}$ & $\begin{array}{l}\text { - Teacher tried to relate the } \\
\text { teaching with the previous } \\
\text { lesson. }\end{array}$ \\
\hline & \multirow[t]{4}{*}{$\begin{array}{l}\text { Question based on } \\
\text { process }\end{array}$} & - Right here 2 electrons right? & \multirow{4}{*}{$\begin{array}{l}\text { - Series of question involving } \\
\text { electrolysis process. } \\
\text { - Beginning from electrolysis } \\
\text { type until the observed product. }\end{array}$} \\
\hline & & $\begin{array}{l}\text { - How many electrons donated...? } \\
\text { - Right here how many electrons } \\
\text { were received? }\end{array}$ & \\
\hline & & $\begin{array}{l}\text { - Is it a positive or negative } \\
\text { electrode? }\end{array}$ & \\
\hline & & $\begin{array}{l}\text { - Is the anode connected to the } \\
\text { positive terminal of the battery or } \\
\text { negative terminal of the battery? }\end{array}$ & \\
\hline & $\begin{array}{l}\text { Comparison } \\
\text { Question }\end{array}$ & $\begin{array}{l}\text { - What is the difference between } \\
\text { molten state and aqueous } \\
\text { solution? }\end{array}$ & $\begin{array}{l}\text { - Between two electrochemical } \\
\text { concepts }\end{array}$ \\
\hline & Question & \multirow{2}{*}{$\begin{array}{l}\text { What did you observe for one } \\
\text { molar of hydrochloric acid? }\end{array}$} & \multirow{2}{*}{$\begin{array}{l}\text { - Question to ensure observed } \\
\text { experiment results }\end{array}$} \\
\hline & $\begin{array}{l}\text { Based on } \\
\text { observation }\end{array}$ & & \\
\hline & $\begin{array}{l}\text { Question of } \\
\text { terminology }\end{array}$ & $\begin{array}{l}\text { - What is the meaning of discharge? } \\
\text { Do you know the meaning of } \\
\text { ores? }\end{array}$ & $\begin{array}{l}\text { Terms related to science } \\
\text { concepts or terms related to the } \\
\text { meaning of English words }\end{array}$ \\
\hline \multirow[t]{2}{*}{$\begin{array}{l}\text { Management } \\
\text { question }\end{array}$} & $\begin{array}{l}\text { Monitoring } \\
\text { question }\end{array}$ & - Can you understand? & $\begin{array}{l}\text { - To ensure the students' } \\
\text { "presence" and promote } \\
\text { teachers' teaching in an } \\
\text { awareness state. }\end{array}$ \\
\hline & $\begin{array}{l}\text { Motivating } \\
\text { question }\end{array}$ & $\begin{array}{l}\text { - Who wants to try? } \\
\text { - Do you have any idea? }\end{array}$ & $\begin{array}{l}\text { - To motivate students to } \\
\text { participate in questions and } \\
\text { answer questions }\end{array}$ \\
\hline
\end{tabular}




\begin{tabular}{|c|c|c|}
\hline Bilingual question & $\begin{array}{l}\text { - Can an electrochemical series of } \\
\text { be constructed? Bolehkah kita } \\
\text { bina siri Elektrokimia? (Malay } \\
\text { language) } \\
\text { - What is the observation at the } \\
\text { electrode? } \\
\text { - What can you observe at the } \\
\text { cathode? } \\
\text { - Why does the ionic compound } \\
\text { encourage the flow of the electric } \\
\text { current, why? }\end{array}$ & $\begin{array}{l}\text { To ensure understanding } \\
\text { through the combination of } \\
\text { English and Malay language } \\
\text { questions. }\end{array}$ \\
\hline Question of prompt & $\begin{array}{l}\text { - Are you ready? } \\
\text { - Can you see the diagram? } \\
\text { - Have you finished? }\end{array}$ & $\begin{array}{l}\text { - To nudge students to prepare } \\
\text { early at the beginning of the } \\
\text { lesson } \\
\text { - To ask students to stop their } \\
\text { activity }\end{array}$ \\
\hline
\end{tabular}

\subsection{Questions Based on Content}

The findings showed that the teachers started the lesson with questions to engage students' knowledge related to the electrochemistry concepts. The concepts that related to electrochemistry were either from the same chapter ora previous chapter studied at the same level or a lower secondary level. This type of question is categorized as a prompt question related to the teaching content. The questions used at the beginning of the teaching session aimed to connect the basic concepts of knowledge. This excerpt shows an example of a question posed in the beginning of a session:

Nora Okay! Students, I want to ask about the previous lesson. We have learned about electrolytes and non-electrolytes. Okay, (1) give me one example of an electrolyte? Nabhan!

( ...)

Nora lead bromide, so ionic compound. (4) Nabhan! .... Non-electrolyte?

[N,4B,P2(240608)/6-24]

The teacher Nora pointed to Nabhan and asked him to give an example of an electrolyte and non-electrolyte that they had learned in the previous week's electrochemistry lesson. The teacher used this type of question not only at the beginning of the lesson, but also later in the lesson, especially when students were non-responsive to the teachers' questions. In addition, the basic concept could also be constructed through students' relationships with their surroundings. This matter is needed in the development of one concept of understanding (Cook, 2006), and the knowledge developed will be more meaningful and easy to understand (Othman, 2007). The concepts of development are arranged accordingly in a hierarchy ranging from easy to difficult in the chemistry curriculum (Daniel, 1999; Othman, 2007). Thus, basic concepts should be conquered in the beginning of the session so that it is readily stored in students' memory.

The second type of question is the process-based question. This type of question is done in sequence. It is a series of questions posed in sequence and related to one another because it involves a process. Answers for one question have a direct link to the next question. A series of sequence questions can form the overall understanding toward one concept included in the process. The sequence of questions can be created step by step, starting with the first fundamental question. This was explained by the teacher Salina as follows:

Why do the students not understand?...when they do not understand the concept. To answer the question or to tell the process of electrochemistry, start from step one until step six. When they are stuck in the first step, they can't continue to tell the process until the end. It is the same for answering the question: When the answer is wrong at the beginning, the next answer will be affected and could be wrong. For example, the electrolysis of sodium chloride- they should first know what are the ions found, and they should have four ions. If the ions listed are wrong, they cannot answer the products of electrolysis. They will get the wrong product. So, when the 
fundamental concept is not good, they do not understand the whole concept of electrochemistry.

[S,TB3(090409)/113-124]

According to the teacher Salina, the answer to the first question has a direct link with the next question. A series of sequence questions can help shape the overall understanding toward one concept that involves a process. The sequence of questions can be posed in a step-by-step process, starting with the basic idea. If the students cannot answer the prompt questions, then the next question cannot be answered correctly. This type of question is given either theoretically or experimentally. This question is used to guide the students to describe the process that takes place in sequence as it can be abstract. It can help students recall and help increase their skills, such as sequencing (Carin, 1993).

A large amount of electrochemical teaching methods involve practical activities. Thus, electrochemistry practical activities are needed. Questions based on observation are usually posed by teachers based on what students are observing. All the teachers in this study posed these types of questions in order to find out what their students had observed. This question is the main question for initiating the discussion about how the experiment was carried out. The following dialog shows the questions on observation asked by the teacher Salina:

\begin{tabular}{|c|c|}
\hline Nora & $\begin{array}{l}\text { Okay, we carried out the first experiment, which is to study the effect of the } \\
\text { concentration of electrolytes. (...) How should you record your observation? Okay, }(94 \\
\text { Kugen!...for } 1 \text { molar hydrochloric acid, what did you observe? }\end{array}$ \\
\hline Kugen & (Kugen stand up) Hydrogen is collected at the anode. \\
\hline Nora & $\begin{array}{l}\text { Hydrogen is collected at the anode. (95) Can you observe the hydrogen or can } \\
\text { the bubbles say...ooh, I'm hydrogen, I'm hydrogen? (The teacher waves her hand) }\end{array}$ \\
\hline Student & Hydrogen gas. \\
\hline Nora & $\begin{array}{l}\text { Hydrogen gas...(96) Did the bubbles say that they are hydrogen?...(97) How do you } \\
\text { know? (98) What did you observe?... }\end{array}$ \\
\hline Student & Observed by using the burning splinter \\
\hline Nora & Observed, (99) What did you observe? \\
\hline Student & The...the...wooden splinter (hesitate) \\
\hline Nora & $\begin{array}{l}\text { Okay, you should state that the colorless bubbles produced...colorless bubbles...you } \\
\text { cannot see the hydrogen but you can see colorless bubbles. }\end{array}$ \\
\hline
\end{tabular}

[S,4I,P4(240708)/593-617]

These questions persuaded the students to describe the process that takes place in the electrolysis process as if they are doing observations. Hence, questions based on observations were still posed when teaching theoretical ideas (even if practical activity is not carried out), especially in the ICT approach. The ICT approach helps students describe ion movement at the cathode and anode, electron movement from anode to cathode until the circuit is completed, and the erosion and sedimentation process. Questions are based more on observations that can be seen through the animations that depict the complex process.

Electrochemistry consists of two main concepts: the electrolytic cell and the Voltic cell. These two concepts are different in terms of the energy changes that take place during the electrolysis process. Differences are also found between electrolytes and non-electrolytes, molten and aqueous solutions, anode and cathode, Daniel and Voltic cells, and positive and negative terminals. Students must be able to compare and contrast between the pairs. Thus, compare and contrast questions are frequently asked by the teachers to ensure that students realize the existence of differences between the two opposing concepts. This type of question gives students the chance to think at a higher level, as discussed by Nora:

Comparison questions always appear on the public exam. I am familiar with these questions. The exam paper did not appear out only on the electrolysis cell or the voltaic cell, but they will ask the differences ... even if we learn one by one. The question usually wants students to compare. This type of question encourages the students to think. This is a part of thinking skills. This question is not a direct question

\section{[N,TB5(120209)/733-738]}

Teacher Nora mentions that students will think by making comparisons between the two concepts. To compare and differentiate is the basic skill in the analysis process in making decisions and solving problems (Subramaniam, 2003). 
Next, the research found that teachers posed questions based on terminology. The terms asked consist of two types; terms related to one concept and terms related to meaning of words. Few terms involve the concept questioned by teachers are like "compound", "electroplating", "purification", "discharge", "electrolyte", "electrolysis", "anode", "cathode" and "Voltic cell". Meanwhile, terms that describe the meaning are "movement", "ores", "more" and "chemical required". Questions based on terms were posed because the terms are basic concepts in Electrochemistry that needed to be understood by students. Without the understanding of these terms, further understanding of electrochemistry will be quite difficult.

\subsection{Questions Based on Management}

In the teaching and learning process, not all questions posed by teachers will be answered by the students. Research has found that teachers face difficulty when posing questions that are not related to teaching content but which help the teaching and learning process. These questions, categorized as management questions, are important and complement the teaching process. According to teachers, these questions give students a chance to think without feeling pressured.

Teachers should always monitor the teaching process by making sure that students can understand the explained lesson. Thus, teachers can use questions such as "understood?", "can you follow?", "did you see that?", "can you see that?", "can you understand?", "you get it?" and "ok?" These questions are used by teachers in a questioning tone during the explanation process about certain steps or concepts. Teachers posed the monitoring questions to ensure that students followed the explanation given. Teachers monitor by asking questions to ensure that students have understood the teacher's explanation. These questions can also help students avoid losing focus, which can affect students' understanding of the teacher's explanation.

If students' give negative responses, then the teacher should be ready to repeat the explanation. Students' responses can also be used as verification before the teachers move on to the next concept as one concept is the combination of systematic sub-concepts, from simple to complex. The sub-concepts interact and increase cumulatively. Monitoring questions are necessary to ensure that students understand and acquire certain concepts so that the understanding and acquisition of the next concept will be easier. When this takes place, it can give the teachers the confidence to continue teaching the next concept and avoid the feeling of being "too engrossed" while teaching.

During the questioning process, the teachers usually had difficulty getting students to respond; thus, teachers took action by giving motivation in the form of questions. Teachers used motivation questions in two situations: motivation to answer and motivation to ask. Motivation questions such as "what else?", "do you remember?", "what is your assumption?", "anybody?", and "who wants to try?" give students the opportunity to volunteer and answer. Meanwhile, some motivation questions posed by the teachers aim to give students the chance to ask for clarity, such as "who wants to ask question?", "anything that you can't understand?", and "is there any problem?" Most questions are open questions that give all students the chance to pose questions. This took place through teachers' teaching.

However, students' reluctance to pose questions was clear even though the teachers gave them chances to do so. This happened because the students felt shy and was scared that the posed questions would be labeled as "stupid questions" by others. In such cases, students feel that they are the only one who do not know about the matter being asked about while others do know about it. Some teachers assume that students do not want to ask the questions even though they are given chances to do so because they are lazy to do not want to think beyond the received matter. This situation probably happened because the students cannot fully understand the concept explained.

Students' questioning depicts how their minds work on the related concepts in their memories. Students' questioning can help divergent learning. However, they might be scared that other students feel that their questions are off topic and not relevant. Clark and Linder (2006) stated that the phenomenon of not asking is a continuation of the teaching approach that takes place at the lower secondary level, where students only listen to teachers without interrupting them.

This study also found that the teachers practiced bilingual questions. First, the teachers posed the question in English, then repeated the same question in the Malay language or vice versa. Second, the teachers posed the questions in English, and then elaborated upon this question using the Malay language. Third, they used both languages; English and Malay, in one question posed to the student (refer to Table 2). This was done to ensure that the students understood the questions.

Language can be a problem when the words used have different meanings to the students compared to what is 
understood by the teachers (Kasim \& Yusoff, 2006). In addition, many words used in daily life have different meanings in the science context (Skamp, 2004). Hence, questions' use of the Malay language is practiced by the teachers as they realized that the students' levels of understanding differ; some of them understand English better than others. This research found that bilingual questions were used in the class where students have difficulty understanding terms in English. Hence, the teachers are more comfortable with this way compared to other approaches.

Next, questions in the form of persuasion are used to ensure students' readiness during the teaching and learning process. This involved class management and was practiced at two levels: at the beginning of a session and at the end of the activity. Questions at the beginning of the teaching session persuaded the student to be ready to start the lesson while questions at the end of the activity persuaded the student to complete the activity while preparing them for the subsequent activity. This excerpt showed the question posed by the teacher Roha:

Roha Asiah! Switch on the fan! Okay, ... Okay class, (1) Are you ready?

Student Yes (all students).

Roha Okay! Open your textbook to page 104. Before we start our lesson today ...I'm going to show you a magic show...

[R,4B,P4(070708)/9-14]

Questions like "are you ready?", as posed by the teacher Roha in the excerpt above before she started the magic show, are posed at the beginning of the teaching session. This question signals to the students that they should stop any bad behavior suggesting that they are not ready to learn, like talking, joking, and walking around. Thus, these questions could attract students' attention and give them the opportunity to be ready and listen to the teacher's explanation while preparing for the next activity. Through these questions, teachers also hope for an aggressive response from every student when describing his/her readiness through his/her responses, such as "ok!", "ready!", and "yes!" In this case, if the responses given are not positive or only some of the students respond, then the teachers might conclude that the students are not ready yet. Hence, the teachers would take other steps to attract attention from students who are not yet ready and make sure that other distractions will not occur. Teachers do not begin teaching until the students are fully ready and give their full attention. Teachers assume that the questions that persuade the students to get ready at the beginning of the teaching session are needed to produce a conducive teaching environment.

The questions posed at the end of one activity aimed to persuade students to expedite the activity being carried out. Questions posed by the teachers tended to be similar to "have you finished?" in order to persuade the students to complete the activity quickly; they also signaled to the students that they have to end their activity and prepare for the next activity. Every activity needs a particular time allocation, so teachers must stop the previous activity before beginning the next activity. These questions can serve to expedite students' work on an activity so they can finish it and prepare for the next activity.

The teaching and learning process involves input-process-output. Input involves previous knowledge that needs to be associated with the content through oral questions. The model in Figure 1 displays the important types of questions that highlighted by teachers during the process of teaching electrochemistry. There are two circles indicate the two different types of questions; content questions and management questions. Content questions are those questions related to the content of electrochemistry. The findings of this study highlighted five sub-categories of content questions: recall, process, comparison, observations, and terminology questions. Meanwhile, the management question included questions related to the management of oral questioning, which could be sub-categorized as motivations, prompting, monitoring, and bilingual questions. 


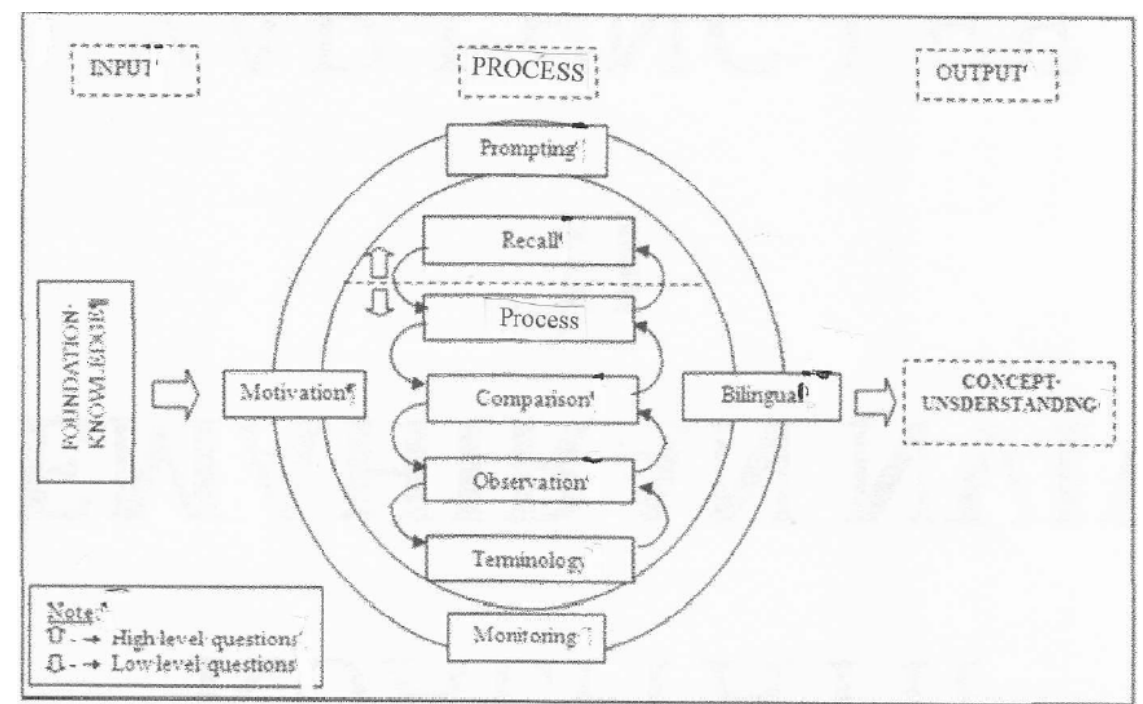

Figure 1. Model of question for teaching and learning process in electrochemical classes

This model shows that the content question is essential in the teaching process, and it is located in the center of the model. A content question begins with the recall question, which could elicit students' knowledge at the beginning of class. The purpose of this question is to test fundamental knowledge learned or acquired from various sources. However, during the questioning process, the students are quite passive and often do not give prompt responses. This is likely due to a lack of understanding. Therefore, teachers need to ask other questions that relate to the concept. In this case, the recall question is used. It is used when students have difficulties understanding the development of the concept. Recall questions posed at the beginning of the lesson provide basic information that is to be associated with the new concept.

This finding showed that teachers used multiple types of questions to ensure students' understanding of a concept. This indicates that questioning is an important factor for students' cognitive development in the teaching and learning process. Cakmak (2009) said that preparing questions is important for ensuring the relationship between the contents being taught and issues already learned, whether at a previous lesson or in relation to the phenomena surrounding them. This type of question helps the teacher construct broad cognitive development on one topic.

Next, the process question is important because electrochemistry consists of electrolysis, molten, and Voltaic cells. At the same time, process questions should be done by comparing the differences of a certain concept in electrochemistry because most concepts in electrochemistry involve comparison, such as electrolyte-non-electrolyte, cathode-anode, negative terminal-positive terminal, and molten-aqueous. The observation question refers to the observations made during experiment. This question is important for ensuring that students understand the processes that occur during the experiment.

Some problems occur when students do not understand the terminology used in the question. Thus, the terminology question focuses on an important term used to ensure that students understand the meaning of scientific words. The analysis showed that most of the content questions used were in the low order thinking level. This model indicates that the low order thinking (LOT) level is more common than higher order thinking (HOT) level because students do not give feedback to the high order thinking question. Thus, high order thinking questions require management questions to ensure that the questioning process runs smoothly.

The questions relating to the content of electrochemistry consisted of the recall, process, comparison, observation, and terminology questions. These questions were important for ensuring that the students could understand certain concepts. These questions depict the structure in electrochemistry. This finding showed that teachers used multiple types of questions to ensure the development of content, further demonstrating that questioning is an important factor for students' cognitive development in the teaching and learning process. it concluded that preparing questions is important for ensuring the relationship between contents being taught related to the issue learned, whether in the previous lesson or related to the phenomena surrounding them. These types of questions help the teacher construct broad cognitive development of one topic.

The management question is stated in the outer model. It is used in the process of oral questioning to achieve the 
learning objectives. This question has four sub-categories: motivation, prompting, monitoring, and bilingual. Teachers often assess students' understanding through homework. Unfortunately, teachers assume that students have a good understanding when they are able to complete the task (Buck \& Trauth-Nare, 2009). In fact, the understanding of certain concepts occurs through oral questions during the teaching process. In this way, misconceptions could be identified and solved spontaneously.

This study found that both types of questions (content and management) complement each other to develop the understanding of electrochemistry concepts. This is important because many concepts in electrochemistry have a strong relationship with smaller concepts at the lower level, learned in the previous chapter or related to the surroundings. From the pedagogical aspect, content questions cannot be achieved without support with management questions. Therefore, some sub-categories in management questions must be used for guidance from the teacher to ensure that the oral questions run smoothly, thereby ensuring that the teaching objectives can be achieved.

\section{Conclusion}

The findings of this study highlighted two main types of questions in the teaching and learning process when teaching electrochemistry. There were questions related to the content and questions related to the teaching management. The questions pertaining to the content covered the topic, which described the knowledge development for electrochemistry. However, other important questions in the teaching and learning process were management questions. Both types of questions practiced by the teachers needed to be used to ensure that the overall teaching and learning process could run smoothly and the objective planned could be achieved successfully.

Teaching strategies should use different types of questions during teaching and learning process to improve the quality of teaching. In addition, different types of questions that involve questions and answers processes between teacher and students and between students and students, either questions regarding content or management needs to be improved so that students could more actively involved in the process of teaching and learning and make learning more meaningful to them.

\section{References}

Arfah, A. A. (1981). Strategies for communication between teachers and pupils in a rural Malaysian school. Singapore: Singapore University Press.

Bachik, M. S. (1999). Pelaksanaan kurikulum sains KBSR dan KBSM di antara hasrat dan amalan: Perspektif Jemaah Nazir Sekolah. Presented paper in Workshop and Conference "Penyelarasan Pembangunan Perisian Kursus Multimedia Pendidikan Interaktif PasukanKhas". Ministry of Education, Malaysia.

Buck, G. A., \& Trauth-Nare, A. E. (2009). Preparing teachers to make the formative assessment process integral to science teaching and learning. Journal of Science Teacher Education, 20(5), 475-494. http://dx.doi.org/10.1007/s10972-009-9142-y

Cakmak, M. (2009). Pre service teachers' thoughts about teachers' questions in effective teaching process. Elementary Education Online, 8(3), 666-675.

Carin, A. A. (1993). Teaching science through discovery: Questioning and listening (7th ed.). New York, NY: Macmillan.

Carlsen, W. S. (1991). Questioning in classroom. Review of Educational Research, 61, 157-178.

Chan, W. K. (1990). Learning difficulties of chemical concepts in the Malaysian Modern Chemistry syllabus (Unpublished master education thesis). Universiti Sains Malaysia.

Chiappetta, E. L., \& Koballa, T. R. (2006). Science instruction in the middle and secondary school: Developing fundamental knowledge and skills for teaching (6th ed.). $\mathrm{OH}$ : Pearson.

Chin, C., \& Kayalvizhi, G. (2002). Posing problems for open investigations: What questions do pupils ask?

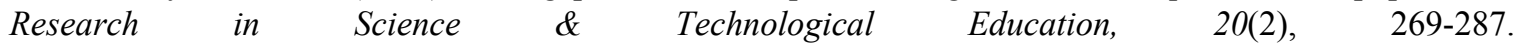
http://dx.doi.org/10.1080/0263514022000030499

Cimer, A. (2007). Effective teaching in science: A review of literature. Journal of Turkish Science Education, $4(1), 20-44$.

Clark, J., \& Linder, C. (2006). Changing teaching, changing times: Lessons from a South Africa township science classroom. Rotterdam, Netherlands: Sense Publishers.

Cook, M. P. (2006). Visual representations in science education: The influence of prior knowledge and cognitive 
load theory on instructional design principles. Science Education, 90(6), 1073-1091. http://dx.doi.org/10.1002/sce.20164

Creswell, J. W. (2003). Research design: Qualitative, quantitative, and mixed method approaches. London, UK: Sage.

Daniel, E. G. S. (1999). Corak konsepsi pelajar bagi konsep 'pertumbuhan' (Unpublished PhD thesis). University of Science Malaysia, Malaysia.

Dillon, J. T. (1990). The practice of questioning. London, UK: Routledge.

Fries-Gaither, J. (2008). Questioning techniques: Research-based strategies for teacher. Energy and the Polar Environment. Retrieved from http://beyondpenguins.nsdl.org/issue/column.php?date=October2008 departmentid=professional\&columnid=professional!as

Jamil, A. (1993). Tinjauan mengenai kekangan-kekangan dalam pelaksanaan sains KBSM di sekolah-sekolah menengah di negeri Kedah Darul Aman (Unpublished master education thesis). Universiti Kebangsaan Malaysia.

Kasim, T. S. A. T., \&Yusoff, Y. M. (2006). Kaedah mengajar dan kemahiran interpersonal guru. Kuala Lumpur: PTS Professional.

Koufetta-Menicou, C., \& Scaife, J. (2000). Teachers' questions: Types and significance in science education. School Science Review, 81(296), 79-84.

Lim, N. R., \& Mahamod, Z. (2007). Peningkatan kualiti penyoalan guru Bahasa Melayu dalam meningkatkan kemahiran berfikir pelajar. Prosiding Seminar Kebangsaan Isu-isu Pendidikan Negara Ketiga (pp. 67-78).

Masrukin, S. H. (2004). Cognitive processes in conceptual change in Electrochemistry among form four Malaysian students (Unpublished $\mathrm{PhD}$ thesis). Faculty of Education, Universiti Malaya.

Merriam, S. B. (2009). Qualitative research: A guide to design and implementation. San Farancisco, CA: Jossey-Bass.

Noraini, I., \& Osman, S. (2009). Pengajarandanpembelajaran. Kuala Lumpur: McGraw Hill Education.

Othman, R. (2007). Budaya sains dan teknologi di kalangan murid sekolah dan hubungannya dengan pertambahan tempoh pembelajaran sains (Unpublished $\mathrm{PhD}$ thesis). Faculty of Education, Universiti Kebangsaan Malaysia.

Parkway, F. W., \& Hardcastle, B. (1990). Becoming a teacher: Accepting the challenge of a profession. Boston, MA: Allyn and Bacon.

Sahin, A. (2007). Teachers' classroom questions. School Science and Mathematics, 107(1), $369-370$. http://dx.doi.org/10.1111/j.1949-8594.2007.tb17759.x

Skamp, K. (2004). Teaching primary science constructively (2nd ed.). Australia: Thomson.

Smith, C. S., \& Barrow, L. H. (1996). Questioning categories used by elementary science teachers during moving and still frames of video disc interaction. Paper presented at the National Association for Research in Science Teaching.

Subramaniam, S. R. (2003). Penyebatian kemahiran berfikir dalam pengajaran kimia secara kontekstual (Unpublished PhD thesis). Faculty of Education, UniversitiKebangsaan Malaysia.

Tamby, S. M. M. (1999). Dampak penyelidikan pembelajaran sains terhadap perubahan kurikulum. Presented paper in Syarahan Perdana Jawatan Profesor, UniversitiKebangsaan Malaysia.

Teixeira-Dias, J. J. C., Jesus, H. P. D., Souza, F. N. D., \& Watts, M. (2005). Teaching for quality learning in chemistry. International Journal of Science Education, 27(9), 1123-1137. http://dx.doi.org/10.1080/09500690500102813

Vella, J. (2008). Open questions invite dialogue. In J. Ashworth (Ed.), On Teaching and learning. San Francisco, CA: Jossey-Bass.

Wilson, N. S., \& Smetana, L. (2011). Questioning as thinking: A metacognitive framework to improve $\begin{array}{lllll}\text { comprehension } \quad \text { of } & \text { expository } & \text { Literacy, } & 45(2), & 84-90 .\end{array}$ http://dx.doi.org/10.1111/j.1741-4369.2011.00584.x

Wragg. E. C., \& Brown, G. (2001). Questioning in the secondary school. London, UK: Routledge/Falmer. 


\section{Copyrights}

Copyright for this article is retained by the author(s), with first publication rights granted to the journal.

This is an open-access article distributed under the terms and conditions of the Creative Commons Attribution license (http://creativecommons.org/licenses/by/3.0/). 